\title{
PENGARUH GAYA KEPEMIMPINAN TERHADAP PENGGUNAAN SISTEM PENGUKURAN KINERJA SERTA IMPLIKASINYA TERHADAP PEMBERDAYAAN PSIKOLOGIS (STUDI EMPIRIS PADA UNIVERSITAS DI PEKANBARU)
}

\author{
Zurman $^{1}$, Vince Ratnawati ${ }^{2}$, Yesi Muthia Basri ${ }^{3}$ \\ 1,2,3 Universitas Riau \\ Kampus Bina Widya, Jalan HR. Subrantas KM. 12.5, Simpang Baru, Panam \\ E-mail : zurmanramadhan18@gmail.com
}

\begin{abstract}
This study aims to find empirical evidence of the influence of leadership style on the use of performance measurement systems and psychological empowerment. The population in this research is all the education staff in the finance department at the University in Pekanbaru namely: 1) University Riau, 2) UIN Sultan Syarif Kasim Riau, 3) Universitas Islam Riau, 4) Lancang Kuning University, 5) Universitas Muhammadiyah Riau, and 6 ) University Abdurrab. The sampling technique used in this study is purposive sampling, with the number of samples of 151 staff of education personnel in the financial section throughout the University in Pekanbaru. The amount of data processed as many as 124 samples by using SEM analysis technique based on Partial Least Square (PLS) by using WarpPLS 5.0. The results of this study conclude: (1) Leadership style influence on psychological empowerment; (2) The use of Performance Measurement System has an effect on psychological empowerment. (3) The use of SPK mediates the relationship between leadership styles towards psychological empowerment.
\end{abstract}

Keywords: Initiating structure leadership, Consideration leadership, Performance Measurement System, Diagnostic, Interactive, Psychological Empowerment

\section{PENDAHULUAN}

Perguruan Tinggi telah memasuki era yang disebut dengan competitive market. Pada era ini tujuan pengelolaan perguruan tinggi tidak hanya untuk mempertahankan eksistensinya tetapi juga untuk memenangkan persaingan dengan perguruan tinggi lain. Bahkan perguruan tinggi di Australia, Amerika, dan Eropa secara langsung harus bersaing untuk mendapatkan mahasiswa (Marginson, 2004, 2006; Angel dkk, 2007; Radianto, 2015). Di Indonesia, ketatnya persaingan antar perguruan tinggi terlihat dari adanya penutupan program studi dan universitas, merger dan akuisisi perguruan tinggi, ditambah lagi banyaknya perguruan tinggi asing masuk ke Indonesai dengan berbagai bentuk dan model perkuliahan (Radianto, 2015).
Oleh karena itu, untuk mempertahankan eksistensi dan memenangkan persaingan, perguruan tinggi membutuhkan Sumber Daya Manusia (SDM) yang handal dimana tidak hanya memiliki kecerdasan namun juga keterampilan (skill) dan perilaku yang baik. Hal ini didasari pada kenyataan bahwa dibanyak organisasi aset intelektual sama pentingnya dengan aset fisik atau finansial (Judge, 2008).

Bila disederhanakan menurut Undang-undang Nomor 20 Tahun 2003 tentang Sistem Pendidikan Nasional, SDM di perguruan tinggi dapat dibedakan menjadi dua, yaitu: tanaga kependidikan dan tenaga pendidik. Undang-undang Nomor 20 Tahun 2003, pasal 39 ayat (1) menyebutkan bahwa tenaga kependidikan bertugas melaksanakan administrasi, pengelolaan, pengembangan, pengawasan, dan pelayanan teknis untuk menunjang proses pendidikan pada satuan 
pendidikan, sedangkan tenaga pendidik merupakan tenaga profesional yang bertugas merencanakan dan melaksanakan proses pembelajaran, menilai hasil pembelajaran, melakukan pembimbingan dan pelatihan, serta melakukan penelitian dan pengabdian kepada masyarakat, terutama bagi pendidik pada perguruan tinggi.

Kinerja dari tenaga kependidikan sebagai unsur penunjang proses pendidikan harus diperhatikan keberadaannya guna mendukung dan memperlancar unsur-unsur lain yang ada di Universitas. Berdasarkan prasurvei yang peneliti lakukan dengan melihat kinerja dari tenaga kependidikan bagian keuangan pada salah satu Universitas negeri di wilayah Pekanbaru, peneliti menemukan rendahnya kinerja tenaga kependidikan dibagian tersebut, hal ini dapat dilihat dari perilaku mereka dalam bekerja yang bersikap apatis, rendahnya realisasi anggaran pada beberapa akun belanja yang menjadi penggerak operasional perguruan tinggi. Hal tersebut memberikan dampak pada penyelenggaraan pendidikan, contohnya keterlambatan pembayaran honor dan gaji tenaga kependidikan, dosen tetap non-pns dan dosen luar biasa yang akan mengakibatkan rendahnya kinerja mereka dalam memberikan pelayanan, pendidikan dan pengajaran, yang tentu saja akan berimplikasi kepada rendahnya kualitas pelayanan dan lulusan. Tentu hal tersebut akan berdampak buruk bagi Universitas untuk memenangkan persaingan. Penyebab rendahnya kinerja karyawan pada bagian keuangan diindikasikan karena masih kurangnya motivasi mereka. Pada umumnya kinerja yang tinggi dihubungkan dengan motivasi yang tinggi dan sebaliknya, motivasi yang rendah dihubungkan dengan kinerja yang rendah (Yusuf, 2014).

Tenaga kependidikan memiliki peran yang sangat penting dalam pelaksanaan operasional, karena itu tenaga kependidikan harus melaksanakan tugas dan fungsinya secara profesional dan penuh dedikasi. Seluruh tenaga kependidikan pada Universitas perguruan tinggi harus melaksanakan tugas dan fungsinya dengan baik, agar Dosen, mahasiswa serta masyarakat umum yang menggunakan pelayanan dari pegawai yang bersangkutan merasa puas (Danter, dkk., 2013).

Namun, keberadaan tenaga kependidikan yang handal, cerdas secara intelektual, memiliki keterampilan dan memiliki perilaku yang baik, tidak akan memberikan kontribusi kepada pencapaian tujuan, jika mereka tidak berkeinginan untuk bekerja keras dengan memaksimalkan semua potensi yang dimilikinya, oleh karena itu motivasi dari setiap tenaga kependidikan perlu ditingkatkan.

Stephen P. Robbins dan Timothy A. Judge (2008) mendefenisikan motivasi sebagai proses yang menjelaskan intensitas, arah dan ketentuan usaha untuk mencapai tujuan. Sejalan dengan hal tersebut, George dan Jones (2005) mengartikan motivasi sebagai suatu kekuatan psikologis dari dalam diri yang menjadi penentu arah perilaku seseorang, tingkat usaha dan kegigihan dalam menghadapi rintangan.

Pada dasarnya, motivasi dapat bersumber dari dalam diri seseorang (motivasi intrinsik) dan dapat pula bersumber dari luar diri seseorang (motivasi ekstrinsik) (Abbas, 2013; Siagian, 2002). Dibandingkan dengan motivasi ekstrinsik, motivasi intrinsik dinilai dapat memberikan dampak lebih besar, karena tertanam langsung didalam diri setiap individu sehingga aktif atau berfungsinya tidak perlu mendapat rangsangan dari luar, dikarenakan dalam diri setiap individu sudah ada dorongan untuk melakukan sesuatu. Motivasi intrinsik dalam realitasnya lebih memiliki daya tahan, dibandingkan dengan 
Jurnal Ilmiah Ekonomi dan Bisnis

Vol. 15. No. 2, September 2018: 186-211

EISSN : $2442-9813$

ISSN : $1829-9822$

motivasi ekstrinsik. Hal ini dikarenakan, faktor ekstrinsik dapat saja justru mengakibatkan menurunnya daya motivasi individu ketika faktor ekstrinsik tersebut mengecewakan.

Motivasi intrinsik menjadi faktor penentu seseorang sadar akan tanggungjawab dan pekerjaannya sehingga dia dengan suka rela mengerjakan pekerjaannya dengan maksimal. Spreitzer

menyebutnya pemberdayaan psikologis (psychological empowerment).

Pemberdayaan psikologis merupakan peningkatan motivasi intrinsik yang dimanifestasikan kedalam empat kognisi, yaitu: meaning, competence, self determination dan impact, yang merefleksikan sikap proaktif yang berorientasi kepada pekerjaan. Meaning merupakan keyakinan dan nilai-nilai yang dimiliki oleh seseorang, sehingga orang tersebut merasa bahwa pekerjaan yang dilakukan sekarang, sangat penting dan berarti bagi dirinya. Competence merupakan kepercayaan atau keyakinan seseorang memiliki keterampilan dan kemampuan yang diperlukan untuk melakukan tugas atau pekerjaan dengan baik. Self-determination merupakan keyakinan memiliki kebebasan atau otonomi dan kendali tentang bagaimana mengerjakan secara mandiri. Impact merupakan persepsi bahwa seseorang memiliki pengaruh secara signifikan terhadap strategi, administrasi dan hasil operasi kerja organisasi. Keseluruhan dimensi kognisi tersebut menjadi sebuah kesatuan yang membentuk keseluruhan dari konstruk pemberdayaan psikologis, sehingga jika salah satu saja dimensi tidak terpenuhi, maka tingkat pemberdayaan yang diperoleh tidak akan maksimal.

Spreitzer (1995) menjelaskan bahwa pemberdayaan psikologis merupakan bentuk konstruk kognitif yang mengacu kepada motivasi intrinsik setiap individu yang berguna sebagai dorongan untuk meningkatkan kinerja. Dengan kata lain, bahwa seseorang yang diberdayakan secara psikologis, motivasi intrinsik dalam dirinya akan meningkat (Sukrajap, 2006), begitu juga dengan kinerjanya (Castro dkk, 2008; Maulana dkk, 2015). Apablia seseorang menganggap pekerjaannya bernilai bagi dirinya, maka motivasinya dalam bekerja juga akan meningkat, sehingga semakin besar pengaruh yang dapat diberikan oleh seseorang pada pekerjaannya maka perannya untuk pekerjaan besar dan motivasi intrinsik akan meningkat dengan semakin besar tanggungjawab yang dipegangnya (Purnawati dan Yuniarta, 2016).

Pemberdayaan psikologis merupakan faktor penting yang menjadi pendorong tenaga kependikan yang merupakan salah satu SDM pada perguruan tinggi mau bekerja keras dengan memaksimalkan semua potensi yang dimilikinya. Menurut Yukl (2005), keberhasilan suatu organisasi memberdayakan SDM secara psikologis, akan memberikan konsekuensi yang menguntungkan, yaitu:

a. Komitmen tugas yang lebih kuat;

b. Inisiatif yang lebih besar dalam menjalankan tanggungjawab peran;

c. Ketekunan yang lebih besar dihadapan rintangan;

d. Lebih inovatif dan berorientasi pada pembelajaran;

e. Optimisme yang lebih kuat tentang keberhasilan akhir dari pekerjaan tersebut;

f. Kepuasan yang lebih tinggi;

g. Komitmen organisasi yang lebih kuat;

h. Berkurangnya pergantian karyawan. Selain itu, bukti empiris menunjukkan bahwa membangun motivasi akan memberikan dampak positif yang signifikan terhadap kinerja keuangan organisasi melalui peningkatan komitmen pekerja, turnover, produktivitas lebih tinggi dan daya tarik bagi pekerja terampil 
dan berpengalaman (International Labour Organizatioin, 2013). Karena itu, dapat disimpulkan pemberdayaan psikologis merupakan fundamental dan aspek yang luar biasa untuk pencapaian keberhasilan pertumbuhan bisnis dan meningkatkan produktivitias (Akbar dkk, 2011).

Salah satu faktor yang menjadi penentu keberhasilan organisasi dalam memberdayakan SDM secara psikologis adalah Sistem Pengendalian Manajemen (SPM). SPM merupakan satu set sistem dan prosedur yang diformalisasikan dan digunakan untuk mempengaruhi perilaku dan aktivitas manajemen dalam rangka mencapai tujuan organisasi (Marginson, 2002; Anthony dan Govindarajan, 2007). Efektifitas dari SPM dapat dilihat dari kemampuannya dalam memotivasi SDM, sehingga mereka mampu untuk meningkatkan kreatifitas individu dan meningkatkan kemampuan kapabilitas perusahaan untuk memenangkan persaingan (Lora, 2016; Radianto, 2015; Ismail, 2013; Wongkaew, 2013; Chia, 2012; Carenys, 2012; Tupamahu, 2009).

Pada hakikatnya SPM pada organisasi bisnis tidak memiliki perbedaan dengan organisasi non-bisnis (Mahsun, 2006; Merchant dan Stede, 2007), salah satunya Perguruan Tinggi (Radianto, 2015). Bahkan Bobe dan Taylor (2011) dan Jarvenpa dan Lansiluto (2011) menggunakan konsep SPM dari Simons (1995) dalam menginvestigasi penerapan SPM di universitas dalam rangka meningkatkan kinerja individu dan organisasi untuk mencapai keunggulan bersaing (Radianto, 2015).

Sistem Pengukuran Kinerja (SPK) yang merupakan salah satu dari SPM (Syaiful, 2007; Ristauli, 2013) diketahui dapat digunakan untuk memotivasi seseorang untuk lebih giat bekerja (Collins, 1982 dalam Syaiful, 2007; Ristauli, 2013). Banyak peneliti meyakini informasi kinerja dapat memotivasi manajer dengan cara memberikan umpan balik terhadap perilaku kerja mereka (Collins, 1982; Luckett dan Eggleton, 1991; Ilgen dkk, 1979 dalam Hall, 2004; Marginson dkk, 2014; Khairiyah, 2015). Hal tersebut sejalan dengan teori umpan balik yang menyatakan bahwa informasi tentang kinerja dapat meningkatkan motivasi seorang manajer (Ilgen dkk, 1979 dalam Hall, 2004).

SPK dapat digunakan secara diagnostic dan interactive (Henri, 2006; Widener, 2007; Mundy, 2010; Fanco Santor, dkk., 2012; Tessier dan Otley, 2012; Marginson dkk, 2014; Khairiyah, 2015; Hernando, 2016). Penggunaan SPK secara diagnostic memfokuskan peranan sistem pengendalian sebagai alat pengawasan, alat mengukur capaian kinerja dan sebagai alat untuk membandingkan kinerja tersebut dengan standar yang telah ditetapkan (Simons, 1994; 1995; 2000). Sedangkan penggunaan SPK secara interactive memfokuskan kepada peran pemimpin untuk secara pribadi dan teratur melibatkan diri mereka bersama bawahan didalam setiap aktivitas pengambilan keputusan (Simons, 2000).

Dalam upaya meningkatkan motivasi SDM pada perguruan tinggi melalui pemberdayaan psikologis selain keberadaan SPM, peran dari seorang pemimpin tidak dapat diabaikan begitu saja. Thompson (2000) menjelaskan bahwa efektifitas dari suatu organisasi sangatlah ditentukan oleh peran seorang leader guiding yang akan membawa anggota organisasi dan kelompok ke arah pencapaian tujuan, visi dan misi dari suatu organisasi.

Menurut John Kotter (dalam Robbins, 2009) pemimpin merupakan pihak yang menentukan arah dengan cara mengembangkan suatu pandangan kedepan, setelah itu mengarahkan bawahan dengan cara mengkomunikasikan pandangan tersebut serta mengispirasi bawahan untuk 
Jurnal Ilmiah Ekonomi dan Bisnis

Vol. 15. No. 2, September 2018: 186-211

EISSN : $2442-9813$

ISSN : $1829-9822$

melewati tantangan. SPK yang merupakan salah satu aspek penting dari SPM digunakan oleh pimpinan untuk memastikan bahwa SDM akan berperilaku sesuai dengan harapan organisasi. Sebagai sebuah alat, efektifitas SPM dipengaruhi oleh pimpinan. Desain dan implementasi dari SPM yang dibentuk dan dijalankan tentu tidak terlepas dari karakteristik pemimpin itu sendiri. Setiap individu memiliki pendekatan atau cara yang berbeda-beda dalam mensetting visi dan mengkomunikasikan hal tersebut kepada pegawai; pendekatan yang berbeda untuk berkomunikasi; perbedaan pada sejauh mana karyawan telah diberdayakan dan perbedaan pada cara bagaimana visi diimplementasikan melalui monitoring dan pilihan pengendalian (Abernethy, dkk., 2014).

Setiap pemimpin memiliki kewenangan dan kewenangan tersebut memungkinkan mereka untuk menetapkan struktur, menentukan strategi prioritas, mengimplementasikan pengendalian formal, menetapkan sasaran, dan kemudian mengambil tindakan untuk mengkoreksi penyimpangan (Arbenethy, 2010). Wewenang itu juga merupakan kecenderungan perilaku dan sifat-sifat pribadi yang berhubungan dengan pemimpin yang akan mempengaruhi cara mereka dalam menggunakan pengendalian dalam mempengaruhi perilaku bawahan (Hunt and Conger, 1999; Waldman dan Yammarino, 1999; Waldman et al, 2001; Yukl, 2005).

Gaya kepemimpinan yang membentuk desain dan impelementasi SPM akan menjadi sarana bagi pemimpin dalam melaksanakan fungsi pengendaliannya dan menjadi sarana dalam menyalurkan nilai-nilai perusahaan kepada karyawan (Ayu, 2013). Maka dapat disimpulkan bahwa, efektifitas dari pemilihan dan penggunaan SPK dalam memotivasi bawahan, tergantung kepada karakteristik pribadi dan cici-ciri pemimpin sebagai pengguna dari SPK tersebut, yang tentu perbedaan dari gaya setiap pemimpin dalam merencanakan, menyusun, memilih dan mengimplementasikan SPK akan memberikan dampak psikologis yang berbeda-beda. Sejalan dengan hal tersebut Efferin dan Hartono (2012) menyatakan bahwa desain dan implementasi dari SPK tidak dapat dipisahkan dari gaya kepemimpinan.

Selain itu, pemimpin dengan gaya kepemimpinannya dapat menciptakan motivasi yang tinggi pada setiap bawahan, sehingga dengan motivasi tersebut akan meningkatkan motivasi intrinsik dan tentu pemberdayaan psikologis juga akan meningkat. Dengan demikian, selain melalui penggunaan SPK, gaya kepemimpinan secara langsung juga mempengaruhi pemberdayaan psikologis.

Pemaparan tersebut memperlihatkan bahwa hubungan antara gaya kepemimpinan, penggunaan SPK dan pemberdayaan psikologis di Perguruan Tinggi sangat penting dan menarik untuk diteliti. Penelitian ini fokus kepada bagaimana gaya kepemimpinan (dalam hal ini initiating structure dan consideration) secara langsung dapat mempengaruhi pemberdayaan psikologis. Selain itu, peneliti juga akan melihat bagaimana pengaruh dari gaya kepemimpinan (dalam hal ini initiating structure dan consideration) terhadap penggunaan SPK secara diagnostic maupun interactive, dan pengaruh dari penggunaan SPK secara diagnostic maupun interactive terhadap pemberdayaan psikologis. Ada beberapa alasan pemilihan fokus dalam penelitian ini.

Pertama, penelitian yang dilakukan oleh Syaiful, dkk., (2007) dan Marginson, dkk., (2014) tidak dapat menjawab pertanyaan tentang gaya kepemimpinan untuk setiap instrumen yang ada. Kedua, masih adanya perbedaan hasil penelitian 
tentang pengaruh dari penggunaan pengukuran kinerja baik secara diagnostic maupun interactive terhadap pemberdayaan psikologis. Hasil penelitian Syaiful dkk., (2007) membuktikan bahwa SPK tidak terbukti meningkatkan pemberdayaan psikologis, namun penelitian Marginson, dkk., (2014) dan Diah, (2015) mengungkapkan bahwa penggunaan SPK secara interactive berpengaruh secara signifikan terhadap pemberdayaan psikologis. Adanya perbedaan hasil penelitian ini disebabkan karena adanya perbedaan faktor-faktor organisatoris dan faktor situasional seperti perilaku individu (kejelasan peran dan pemberdayaan psikologis) pada tiap-tiap perusahaan. Karena itu mengacu kepada teori kontinjensi, dimana premis dari teori kontijensi adalah tidak terdapat sistem pengendalian yang secara universal selalu tepat untuk bisa diterapkan pada seluruh organisasi dalam setiap keadaan (Otley, 1980; Syaiful, 2007), maka SPK perlu digeneralisasi dengan mempertimbangkan faktor organisatoris dan situasional seperti perilaku individu dalam hal ini pemberdayaan psikologis agar dapat diterapkan secara efektif.

Ketiga, penelitian sebelumnya (Hartman, dkk., 2010; Marginson, dkk., 2014; Khairiyah, 2015; Lora, 2016) selama ini melihat persepsi dari manajer atas dan manajer menengah. Penelitian ini sebagaimana penelitian yang dilakukan oleh Hernando (2016), akan mencoba melihat persepsi dari sumber yang berbeda, yaitu bawahan. Alasan memilih bawahan sebagai sampel penelitian adalah bawahan sebagai individu yang terlibat langsung dengan pemimpin, merekalah yang lebih mampu menilai bagaimana gaya pemimpin mereka serta bagaimana penggunaan SPK mempengaruhi mereka secara psikologis. Hal tersebut didukung oleh Lee dkk., (2015) yang menyatakan bahwa bawahan menjadi sumber yang tepat untuk menilai pimpinan mereka dalam menggunakan gaya kepemimpinan dan pengukuran kinerja (Lee, dkk., 2015). Berdasarkan uraian tersebut, peneliti akan menguji pengaruh gaya kepemimpinan terhadap penggunaan sistem pengukuran kinerja secara interactive maupun diagnostic serta implikasinya terhadap pemberdayaan psikologis pada Universitas di Pekanbaru.

\section{TINJAUAN PUSTAKA \\ Goal Setting Theory}

Dalam mengembangkan hipotesis dan teori, penelitian ini menggunakan goal setting theory yang dikembangkan oleh Edwin A Locke (1968) sebagai landasan berpikir. Beberapa literatur penting terkait pengukuran kinerja dan control system serta psikologi secara umum menyarankan teori ini sebagai teori dasar dalam penelitian dan pengembangan teoritis (Hartman, 2000; Franco Santos dkk, 2012). Teori ini merupakan salah satu bentuk teori motivasi yang menjelaskan bahwa penyebab individu bertindak adalah tujuan (Locke dan Latham, 2013).

Teori ini memprediksi bahwa dengan memiliki tujuan spesifik yang diformalkan dalam SPK strategis, membantu manajer dalam perencanaan dan pengendalian organisasi, menerjemahkan strategi organisasi ke dalam perilaku dan pencapaian yang lebih baik. Argumentasi yang mendasarinya adalah bahwa premis mayor yang mendorong pengembangan SPK yang lebih komprehensif adalah bahwa pengukuran-pengukuran tersebut dapat membantu pencapaian kinerja manajerial yang lebih baik (Epstein dan Manzoni, 1998; Atkinson dan Epstein, 2000). Goal theory menyoalkan bahwa tujuan-tujuan yang secara sadar dipilih seseorang mempengaruhi motivasinya melalui satu dari dalam empat mekanisme yaitu: tujuan membangunkan usaha mencapai tujuan, 


\section{Jurnal Ilmiah Ekonomi dan Bisnis}

Vol. 15. No. 2, September 2018: 186-211

EISSN : $2442-9813$

ISSN : 1829-9822

tujuan mengarahkan perhatian dan usaha ke arah tujuan, tujuan meningkatkan ketekunan untuk berusaha, dan tujuan mempengaruhi tindakan secara tidak langsung dengan mendorong ke arah pemicu, penemuan, dan/ atau penggunaan pengetahuan terkait dengan penyelesaian tugas (task-relevant knowledge) dan strategi (Locke dan Latham, 1990; 2002; Mitchell dan Daniels, 2003; Birnberg, dkk., 2006).

\section{Gaya Kepemimpinan}

Kepemimpinan merupakan topik yang paling populer dalam ilmu sosial dan seringkali digunakan untuk menggambarkan kesuksesan perusahaan (Huang, 2015). Pada dasarnya kepemimpinan merupakan salah satu kunci penting dari efektifitas fungsi manajemen, karena kepemimpinan dapat memberdayakan serta mengarahkan sumber daya yang ada secara efekif dan efisien.

Menurut

Draft

(2006)

kepemimpinan adalah kemampuan mempengaruhi orang-orang untuk mencapai tujuan organisasional. Lebih spesifik Dubrin (2001) mendefenisikan kepemimpian selain kemampuan untuk mempengaruhi, merupakan kemampuan untuk menanamkan keyakinan guna memperoleh dukungan dari anggota organisasi untuk mencapai tujuan organisasi.

Setiap pemimpin memiliki gaya yang berbeda-beda antara satu dengan yang lainnya. Gaya kepemimpinan merupakan gaya yang digunakan untuk mempengaruhi orang lain agar memahami dan setuju tentang apa yang perlu dilakukan dan bagaimana melakukannya, serta proses memfasilitasi upaya individu-individu dan kolektif untuk mencapai tujuan bersama. Dalam penelitian ini, peneliti menggunakan gaya kepemimpinan yang dikemukakan oleh Stogdill dan Coons
(1957) (dalam Hartmann, dkk., 2010; Hernando., 2016) yaitu Iniating Structure Leadership dan Consideration Leadership.

Pemimpin dengan initiating mendefenisikan peran yang jelas, menentukan tugas-tugas tertentu dan bergantung pada penggunaan aturan dan prosedur standar untuk mengarahkan perilaku bawahan dan memantau bawahan terhadap standar yang harus dipatuhi (Abernethy, dkk., 2010). Gaya kepemimpinan Iniatiang Structure menunjukkan sejauh mana seorang pemimpin memiliki kemampuan untuk menetapkan dan menstruktur tugas perannya dan peran bawahannya dalam upaya mencapai tujuan.

Consideration Leadership menunjukkan sejauh mana seorang pemimpin memiliki hubungan kerja dengan bawahannya yang dicirikan oleh saling percaya, menghargai gagasan; dan kepekaan dalam memperhatikan perasaan bawahan. Karakteristik gaya kepemimpinan consideration terlihat dari perlakuan atasan yang memperhatikan kesejahteraan bawahan dan juga menginginkan agar bawahan dapat terlibat dalam pengambilan keputusan di perusahaan (Albernethy, dkk., 2010). Gaya kepemimpinan consideration dapat membangun suasana kerja yang saling percaya antara pimpinan dengan bawahan, menghormati atas ide-ide yang dikemukakan oleh bawahan, dan mempertimbangkan perasaan bawahan.

Gaya kepemimpinan initiating structure dan consideration tidak saling mempengaruhi satu sama lainnya, artinya setiap individu dapat menggunakan gaya initiating structure dan consideration sekaligus, tetapi hanya perbedaan kadar dalam penggunaannya. Maksudnya seorang pemimpin dengan perbedaan gaya kepemimpinan yang dimiliki cenderung menggunakan gaya kepemimpinan initiating structure daripada consideration, 
dan sebaliknya atau menggunakan kombinasi kedua gaya tersebut pada kadar yang sama.

\section{Sistem Pengukuran Kinerja (SPK)}

Pengukuran kinerja menjadi sangat penting, mengingat perannya sebagai kunci dalam implementasi rencana strategis, menterjemahkan strategi kedalam perilaku dan hasil yang diinginkan, mengkomunikasikan harapan, memberikan umpan balik, memantau kemajuan, memotivasi bawahan dengan imbalan dan sanksi, serta mengevaluasi capaian tujuan perusahaan (Chow dan Van der Stede, 2006; Abernethy, dkk., 2010; Sholihin, 2013; Hinkin dan Schriesheim, 2015).

Sistem pengukuran kinerja (SPK) merupakan indikator dan proses pengumpulan data yang dapat menjelaskan, melaporkan dan menganalisa sebuah kinerja (Marshall dkk., 1999). SPK menyediakan pendekatan sistematis untuk menerjemahkan strategi menjadi ukuran tujuan yang dapat dikomunikasikan dengan jelas (Bisbe dan Malagueno, 2012) dan memberikan informasi umpan balik (Widener, 2007). SPK bertujuan untuk mengetahui apakah selama pelaksanaan kinerja terdapat deviasi dari rencana yang telah ditentukan, atau apakah kinerja dapat tercapai sesuai dengan yang diharapkan (Wibowo, 2011).

SPK dapat meningkatkan keefektifan perusahaan, karena memberikan informasi yang relevan kepada para manajer dan informasi tersebut akan digunakan sebagai dasar pertimbangan dalam pengambilan keputusan strategis (Khairiyah, 2015). Sebagai bagian dari dari sistem pengendalian manajemen, SPK dapat digunakan secara diagnostic maupun secara interactive (Henri, 2006; Widener, 2007; Mundy., 2010; FrancoSantor dkk., 2012; Tessier dan Otley,
2012; Marginson dkk., 2014; Khairiyah, 2015; dan Hernando, 2016). Simons (1995; 2000) mendefenisikan diagnostic control system sebagai sistem informasi umpan balik formal yang digunakan untuk memantau hasil organisasi dan mengoreksi penyimpangan-penyimpangan yang terjadi dari standar kinerja yang telah ditetapkan sebelumnya. Diagnostic control system merupakan metode tradisional yang dimaksudkan untuk memberikan motivasi kepada karyawan agar menyelaraskan perilaku mereka dengan tujuan perusahaan (Marginson dkk., 2010; Tessier dan Otley, 2012).

Alasan pimpinan menggunakan diagnostic control system adalah untuk mengimplementasikan strategi secara efektif dan menghemat perhatian manajemen serta mengelola ketidakpastian strategi dan resiko (Simons, 2000). Henri (2006) berpendapat bahwa penggunaan SPK secara diagnostic adalah untuk menentukan tujuan dan sasaran, mengidentifikasikan pencapaian tujuan dan sasaran, mengidentifikasi penyimpangan serta melakukan tindakan lebih lanjut atas penyimpangan. Penggunaan SPK secara diagnostic memfokuskan peranan sistem pengendalian sebagai alat pengawasan, alat mengukur capaian kinerja dan sebagai alat untuk membandingkan kinerja tersebut dengan standar yang telah ditetapkan (Simons 1994; 1995; 2000). Selain itu, penggunaan SPK secara diagnostic akan memberikan informasiinformasi penting yang mempengaruhi kinerja melalui pemberdayaan psikologis kepada pimpinan dan mengharuskan pimpinan untuk fokus terdapat informasi penting tersebut.

Simons

(1994, 2000) mendefenisikan interactive control system sebagai sistem formal yang digunakan oleh pimpinan untuk secara teratur dan aktif melibatkan diri kedalam aktifitas pengambilan keputusan oleh bawahan, dengan tujuan merangsang ide-ide dan 
Jurnal Ilmiah Ekonomi dan Bisnis

Vol. 15. No. 2, September 2018: 186-211

EISSN : $2442-9813$

ISSN : $1829-9822$

strategi baru serta mengarah pada pemberian solusi dalam mengatasi masalah dengan aktif berdialog (Bisbe dan Otley, 2004; Hoque dan Chia, 2012; Tessier dan Otley, 2012). Interactive control system merupakan proses komunikasi dua arah antara manajer dengan bawahan pada berbagai tingkat organisai (Simons, 2000), yang berfokus pada masa depan (forward-looking) yang ditandai dengan secara aktif pimpimpinan melakukan dialog aktif, sehingga interactive control system ini membantu para pimpinan dalam menyediakan suatu mekanisme bagaimana mempelajari peluang strategi baru (Widener, 2007). Tujuan dari interactive control system adalah untuk meningkatkan kemampuan manajer dalam mengantisipasi dan efektifitas mengelola ketidakpastian masa depan (Simons, 2000). Penggunaan SPK secara interactive bertujuan untuk meningkatkan kemampuan pimpinan dalam mengantisipasi dan efektifitas mengelola ketidakpastian masa depan, hal tersebut dapat membantu pimpinan yang belum berpengalaman untuk dapat mengendalikan situasi yang memiliki kompleksitas tinggi (Abernethy dkk, 2010).

\section{Pemberdayaan Psikologis}

Pemberdayaan psikologis adalah keyakinan seorang individu akan kemampuannya untuk melakukan kegiatan kerja terkait dengan keterampilan dan kompetensi (Meyerson, 2008). Pemberdayaan psikologis merupakan konstruk motivasi yang berfokus pada kognisi individu yang diberdayakan (Menon, 2001). Individu yang diberdayakan dapat bekerja dengan lebih baik jika dibandingkan dengan individu yang tidak atau kurang diberdayakan (Castro et al, 2008). Pemberdayaan psikologis merupakan pemberdayaan dalam konstruk motivasional yang merupakan kekuasaan dan kendali yang digunakan sebagai suatu kondisi kepercayaan manusia yang bersifat motivasional (Debora, 2006), bersifat motivasional berarti mengandung harapan, ekspektasi dan bersifat informal yang berasal dari dalam diri setiap individu yang mendorong individu untuk bekerja lebih baik (Khairiyah, 2015).

Spreitzer (1996) mengemukakan dimensi dari pemberdayaan psikologis yang merupakan pengembangan dari apa yang dikemukakan oleh Thomas dan Velthouse (1990) ke dalam 4 (empat) dimensi, yaitu: meaning, competence, self determination, impact. Meaning atau arti merefleksikan derajat seseorang dimana seseorang percaya dan perhatian terhadap maksud suatu tujuan. Kebermaknaan dinilai dengan mengacu kepada standar pribadi seseorang atau berdasarkan standar kebutuhannya; Competence atau kompetensi mengacu pada keyakinan akan kemampuan diri yang spesifik untuk bekerja bersumber pada keyakinan individu pada kapabilitas dan pengetahuannya untuk dapat melaksanakan aktivitas dan tugas dengan keterampilan sehingga dapat mencapai kesuksesan; Self determination atau determinasi diri merepresentasikan tingkatan dimana seseorang merasakan tanggungjawab yang timbal balik untuk tindakan-tindakan yang berhubungan dengan pekerjaan, pada perasaan memiliki pilihan dalam memulai dan mengatur perilaku; Impact atau akibat sebagai sebuah pengalaman memiliki pengaruh yang strategis, administratif ataupun operasional pada pekerjaan yang dapat memberikan perbedaan;

\section{Gaya Kepemimpinan terhadap Pemberdayaan Psikologis}

Dalam upaya meningkatkan motivasi karyawan, peran dari seorang pemimpin tidak dapat diabaikan begitu saja. Thompson (2000) menjelaskan bahwa efektifitas dari suatu organisasi 
sangatlah ditentukan oleh peran seorang leader guiding yang akan membawa anggota organisasi dan kelompok ke arah pencapaian tujuan, visi dan misi dari suatu organisasi. Menurut Abernethy dkk (2010) pemimpin dengan gaya kepemimpinan initiating structure lebih memilih untuk mendefenisikan peran yang jelas, menentukan tugastugas tertentu dan bergantung pada penggunaan aturan dan prosedur standar untuk mengarahkan perilaku bawahan dan memantau bawahan terhadap standar yang harus dipatuhi.

Pemimpin dengan gaya kepemimpinan initiating structure lebih berorientasi kepada pencapaian tujuan organisasi atau dengan kata lain mementingkan hasil (production centered) daripada kepentingan bawahan (employed centered), sehingga pemimpin tersebut cenderung memberikan kritik terhadap pelaksanaan pekerjaan yang kurang baik, menekankan pentingnya batas waktu pelaksanaan tugas, selalu memberitahu apa yang harus dikerjakan dan apa yang tidak boleh dikerjakan, selalu memberikan petunjuk atau cara dalam melaksanakan tugas dengan memberikan standar tertentu atas pekerjaan, selalu mengawasi bagaimana bawahan bekerja, dan cenderung bekerja mengikuti target dalam waktu dan pencapaian.

Pemimpin yang lebih berorientasi pada pencapain tujuan organisasi, tentu pada suatu kondisi akan memberikan pengaruh terhadap motivasi seorang bawahan dalam bekerja. Untuk memotivasi karyawan agar dapat berpretasi dan dapat bekerja sesuai dengan apa yang diinginkan perusahaan dalam rangka mencapai tujuan perusahaan, namun itu semua tidak akan tercapai tanpa adanya motivasi yang kuat.

Lalu, Muchinsky menyebutkan bahwa pimpinan dengan gaya kepemimpinan consideration berhubungan positif dengan dampak psikologis khususnya kepuasan bawahan. Dalam penelitiannya, Hartmann dkk (2010) menemukan bahwa pemimpin dengan gaya kepemimpinan consideration berhubungan positif dengan dampak psikologis keadilan evaluasi dan kejelasan tujuan.

Sejalan dengan hal tersebut, Judge dkk (2004) yang menyebutkan bahwa pemimpin dengan gaya kepemimpinan consideration akan memberdayakan bawahan dan memungkinkan bawahan untuk ikut berpartisipasi mengeluarkan ide-ide mereka dalam proses pembuatan keputusan serta memperlakukan bawahan secara adil melalui pertimbangan individual.

\section{Gaya Kepemimpinan terhadap Penggunaan Sistem Pengukuran Kinerja \\ Menurut John Kotter (dalam} Robbins, 2009) pemimpin merupakan pihak yang menentukan arah dengan cara mengembangkan suatu pandangan kedepan, setelah itu mengarahkan bawahan dengan cara mengkomunikasikan pandangan tersebut serta mengispirasi bawahan untuk melewati tantanga. SPK yang merupakan salah satu aspek penting dari SPM digunakan oleh pimpinan untuk memastikan bahwa SDM akan berperilaku sesuai dengan harapan organisasi. Sebagai sebuah alat, efektifitas SPM dipengaruhi oleh pimpinan. Desain dan implementasi dari SPM yang dibentuk dan dijalankan tentu tidak terlepas dari karakteristik pemimpin itu sendiri. Setiap individu memiliki pendekatan atau cara yang berbeda-beda dalam mensetting visi dan mengkomunikasikan hal tersebut kepada pegawai; pendekatan yang berbeda untuk berkomunikasi; perbedaan pada sejauh mana karyawan telah diberdayakan dan perbedaan pada cara bagaimana visi diimplementasikan melalui monitoring 
Jurnal Ilmiah Ekonomi dan Bisnis

Vol. 15. No. 2, September 2018: 186-211

EISSN : $2442-9813$

ISSN : $1829-9822$

dan pilihan pengendalian (Abernethy, dkk., 2014).

Setiap pemimpin memiliki kewenangan dan kewenangan tersebut memungkinkan mereka untuk menetapkan struktur, menentukan strategi prioritas, mengimplementasikan pengendalian formal, menetapkan sasaran, dan kemudian mengambil tindakan untuk mengkoreksi penyimpangan (Arbenethy, 2010). Wewenang itu juga merupakan kecenderungan perilaku dan sifat-sifat pribadi yang berhubungan dengan pemimpin yang akan mempengaruhi cara mereka dalam menggunakan pengendalian dalam mempengaruhi perilaku bawahan (Hunt and Conger, 1999; Waldman dan Yammarino, 1999; Waldman et al, 2001; Yukl, 2005). Gaya kepemimpinan yang membentuk desain dan impelemntasi SPM akan menjadi sarana bagi pemimpin dalam melaksanakan fungsi pengendaliannya dan menjadi sarana dalam menyalurkan nilai-nilai perusahaan kepada karyawan (Ayu, 2013).

\section{Penggunaan Sistem Pengukuran Kinerja terhadap Pemberdayaan Psikologis}

Salah satu faktor yang menjadi penentu keberhasilan organisasi dalam memberdayakan SDM secara psikologis adalah Sistem Pengendalian Manajemen (SPM). SPM merupakan satu set sistem dan prosedur yang diformalisasikan dan digunakan untuk mempengaruhi perilaku dan aktivitas manajemen dalam rangka mencapai tujuan organisasi (Marginson, 2002; Anthony dan Govindarajan, 2007). Efektifitas dari SPM dapat dilihat dari kemampuannya dalam memotivasi SDM, sehingga mereka mampu untuk meningkatkan kreatifitas individu dan meningkatkan kemampuan kapabilitas perusahaan untuk memenangkan persaingan (Lora, 2016; Radianto, 2015;
Ismail, 2013; Wongkaew, 2013; Chia, 2012; Carenys, 2012; Tupamahu, 2009).

Pada hakikatnya SPM pada organisasi bisnis tidak memiliki perbedaan dengan organisasi non-bisnis (Mahsun, 2006; Merchant dan Stede, 2007), salah satunya Perguruan Tinggi (Radianto, 2015). Bahkan Bobe dan Taylor (2011) dan Jarvenpa dan Lansiluto (2011) menggunakan konsep SPM dari Simons (1995) dalam menginvestigasi penerapan SPM di universitas dalam rangka meningkatkan kinerja individu dan organisasi untuk mencapai keunggulan bersaing (Radianto, 2015).

Sistem Pengukuran Kinerja (SPK) yang merupakan salah satu dari SPM (Syaiful, 2007; Ristauli, 2013) diketahui dapat digunakan untuk memotivasi seseorang untuk lebih giat bekerja (Collins, 1982 dalam Syaiful, 2007; Ristauli, 2013). Banyak peneliti meyakini informasi kinerja dapat memotivasi manajer dengan cara memberikan umpan balik terhadap perilaku kerja mereka (Collins, 1982; Luckett dan Eggleton, 1991; Ilgen dkk, 1979 dalam Hall, 2004; Marginson dkk, 2014; Khairiyah, 2015). Hal tersebut sejalan dengan teori umpan balik yang menyatakan bahwa informasi tentang kinerja dapat meningkatkan motivasi seorang manajer (Ilgen dkk, 1979 dalam Hall, 2004).

SPK dapat digunakan secara diagnostic dan interactive (Henri, 2006; Widener, 2007; Mundy, 2010; Fanco Santor, dkk., 2012; Tessier dan Otley, 2012; Marginson dkk, 2014; Khairiyah, 2015; Hernando, 2016). Penggunaan SPK secara diagnostic memfokuskan peranan sistem pengendalian sebagai alat pengawasan, alat mengukur capaian kinerja dan sebagai alat untuk membandingkan kinerja tersebut dengan standar yang telah ditetapkan (Simons, 1994; 1995; 2000). Sedangkan penggunaan SPK secara interactive memfokuskan kepada peran pemimpin untuk secara pribadi dan teratur 
melibatkan diri mereka bersama bawahan didalam setiap aktivitas pengambilan keputusan (Simons, 2000).

Gambar 1: Model Penelitian

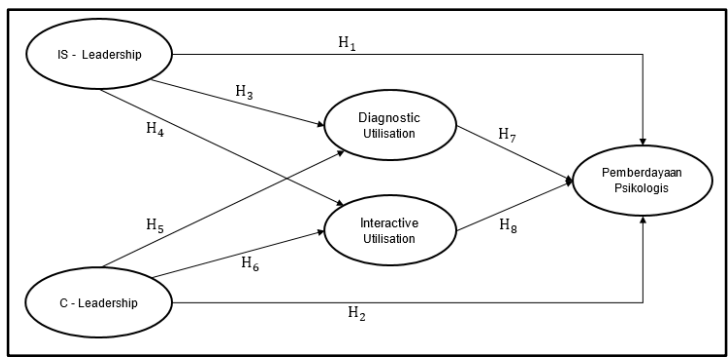

Sumber: Data olahan (2018)

Penggunaan SPK secara

diagnostic dan interactive saling berkaitan dan digunakan bersama-sama (Marginson dkk, 2014). Berdasarkan pemaparan sebelumnya dibentuk sebuah model penelitian yang dapat dilihat pada gambar 1 .

\section{METODE PENELITIAN}

Data yang digunakan dalam penelitian ini adalah data primer. Penelitian ini merupakan penelitian berbasis survei. Populasi dalam penelitian ini adalah seluruh tenaga kependidikan pada Universitas di Kota Pekanbaru, yaitu: (1) Univeristas Riau, (2) UIN Sultan Syarif Kasim Riau, (3) Univeristas Islam Riau, (4) Universitas Lancang Kuning, (5) Universitas Muhammadiyah Riau, dan (6) Universitas Abdurrab.

Teknik pengambilan sampel yang digunakan didalam penelitian ini adalah purposive sampling. Purposive sampling merupakan teknik penentuan sampel dengan pertimbangan tertentu (Sugiyono, 2011). Adapun pertimbangan yang digunakan peneliti dalam menetapkan jumlah sampel penelitian adalah: tenaga kependidikan yang bertugas pada bagian keuangan pada Universitas di Kota Pekanbaru. Berdasarkan pertimbangan tersebut, maka diperoleh jumlah sampel yang akan diteliti dalam penelitian ini yang berjumlah 151 orang.
Secara khusus penelitian ini menggunakan teknik analisis structural equation modeling (SEM) yang berbasis Partial Least Square (PLS). Secara rinci tahapan analisis SEM adalah mengevaluasi model pengukuran (outer model), evaluasi model struktural (inner model) dan uji hipotesis dan interpretasi hasil penelitian.

\section{HASIL DAN PEMBAHASAN}

Dalam penelitian ini 151 kuesioner yang telah disebarkan secara langsung dan tidak langsung ke setiap Universitas di Pekanbaru. Dari 6 (enam) Universitas yang menjadi objek penelitian, tidak semua Universitas yang mengembalikan kuesioner yang telah diserahkan. Dari 151 kuesioer yang disebarkan, hanya 124 kuesioner yang dapat diolah lebih lanjut.

\section{Evaluasi Model Pengukuran (Outer Model)}

Tujuan dari evaluasi model pengukuran adalah untuk mengevaluasi validitas dan reliabilitas indikatorindikator pembentuk konstruk laten. Model pengukuran (outer model) dievaluasi menggunakan uji bias metode umum (common method bias), validitas konstruk dan reliabilitas instrumen.

\section{Uji Bias Metode Umum (Common Method Bias)}

Uji bias metode umum (common method bias) dilakukan untuk memeriksa apakah ada bias yang diakibatkan oleh varian metoda sama atau common method variance yang mempengaruhi korelasi antara variabel-variabel yang diukur dengan menggunakan metode yang sama. Pemeriksaan common method bias dapat dilihat melalui nilai VIF (Variance Inflation Factor) setiap variabel penelitian. Knock dan Lynn (2012) merekomendasikan penggunaan nilai 3,3 sebagai batasan kolinearitas. Bahwa nilai full collinearity VIF semua konstruk variabel penelitian yakni IS-L, C-L, SPK- 
Jurnal Ilmiah Ekonomi dan Bísnis

Vol. 15. No. 2, September 2018: 186-211

EISSN : $2442-9813$

ISSN : $1829-9822$

D, SPK-I, dan PP dibawah batasan maksimum 3,3. Dengan demikian dapat disimpulkan bahwa tidak terjadi masalah kolinearitas pada seluruh konstruk variabel didalam penelitian ini.

\section{Uji Validitas}

Uji validitas dilakukan untuk mengetahui seberapa tepat instrumen atau indikator-indikator tersebut mampu untuk mengukur apa yang hendak diukur. Dalam penelitian ini, validitas pengukuran yang diuji adalah construct validity (validitas isi). Validitas ini dibedakan menjadi dua yaitu validitas konvergen dan validitas diskriminan. Terdapat beberapa cara yang bisa dilakukan untuk mengevaluasi validitas konvergen, namun menurut Hair dkk, (2006) validitas konvergen item-item pengukuran cukup ditunjukkan dengan nilai loading factor, AVE, dan composit reliability $(C R)$. Nilai loadiing factor dari item-item pengukuran seluruh variabel penelitian berada diatas batasan minimum nilai loading factor yang disyaratkan $(<0,001)$. Lalu mengacu pada persyaratan nilai AVE dan CR yang terdapat pada tabel.3 dapat dilihat bahwa masing-masing indikator memiliki nilai AVE diatas 0,50 dan memiliki composit reliability (CR) diatas 0,700 dapat diartikan bahwa seluruh item-item pengukuran setiap variabel penelitian telah memenuhi persyaratan validitas konvergen atau dapat dikatakan bahwa item-item pengukuran setiap variabel valid.

Akar AVE pada kolom masingmasing variabel konstruk seperti gaya kepemimpinan initiating structure (ISL), gaya kepemimpinan consideration (C-L), penggunaan SPK secara diagnostic (SPK-D), penggunaan SPK secara interactive (SPK-I) dan pemberdayaan psikologis (PP) pada posisi diagonal lebih tinggi daripada korelasi antarvariabel laten pada kolom selain diagonal (off-diagonal), hal ini menunjukkan bahwa validitas diskriminan terpenuhi.

\section{Uji Reliabilitas}

Reliabilitas dari suatu pengukuran mengindikasikan stabilitas dan konsistensi dari instrumen yang mengukur suatu konsep dan berguna untuk menguji suatu "kebaikan" dari pengukuran tersebut (Sekaran, 2003:203 dalam Latan, 2014:97). Terdapat 2 (dua) kriteria dalam mengukur atau mengevaluasi reliabilitas yakni dengan melihat nilai indicator reliability dan internal consistency reliability.

Indicator reliability merupakan besaran variance dari indikator/ item untuk menjelaskan konstruk laten (Ghozali \& Laten, 2014). Sedangkan internal consistency reliability menggambarkan estimasi dari reliabilitas berdasarkan pada rata-rata korelasi antar item-item di dalam sebuah pengujian (Laten, 2014). Hasil uji reliabilitas dengan kriteria indicator reliability dilihat dari nilai cronbach's alpha, dan uji reliabilitas dengan kriteria internal consistency reliability dilihat dari nilai composite reliability. Model pengukuran menunjukkan reliabilitas apabila nilai cronbach's alpha minimal 0,70 dan nilai composite reliability minimal 0,60 namun disarankan 0,70; Seluruh nilai dari cronbach's alpha dan composite reliability variabel konstruk laten gaya kepemimpinan IS-L gaya kepemimpinan C-L, SPK-D, penggunaan SPK-I dan PP lebih besar dari batasan minimum nilai 0,70. Hal ini menunjukkan bahwa reliabilitas telah terpenuhi.

\section{Evaluasi Model Struktural}

Evaluasi model struktural atau inner model dilakukan untuk memperoleh hasil estimasi koefisien jalur dan tingkat signifikansi yang kemudian akan digunakan untuk melihat hubungan antar variabel laten berdasarkan pada teori substantif. Pada tahap ini, diagram jalur 
disajikan berupa model lengkap (full model) yang terdiri dari model struktural beserta model pengukurannya. Ukuran yang digunakan untuk mengevaluasi seberapa baik atau fitnya full model adalah goodness of fit. Dari sejumlah ukuran/ indeks fit yang tersedia, peneliti akan menggunakan ukuran indikatorindikator fit yaitu average $R$-Squared (ARS), average variance inflation factor (AVIF), dan average path coefficient (APC).

Tabel 1 : Nilai Ukuran Indikatorindikator fit

\begin{tabular}{llllll}
\hline & ARS & & $\begin{array}{l}\text { AVI } \\
\text { F }\end{array}$ & APC & \\
$\begin{array}{l}\text { Model } \\
\text { fit }\end{array}$ & & & & & \\
indice & 0,31 & $<0,00$ & 1,050 & 0,35 & $<0,00$ \\
$\boldsymbol{s}$ and & 1 & 1 & & 3 & 1 \\
$P$ & & & & & \\
values & & & & &
\end{tabular}

Sumber: Data Primer Diolah, WarpPLS 5.0 .

Dari tabel di atas dapat dilihat perolehan nilai ukuran indikator average $R$-Squared (ARS) sebesar 0,311 dengan p-value 0,001 , average path coefficient (APC) sebesar 0,353 dengan $\mathrm{p}$ value $<0,001$, dan nilai average variance inflation factor (AVIF) sebesar 1,050 menunjukkan bahwa model struktural telah memenuhi kriteria, dengan kata lain bahwa model struktural penelitian mempunyai fit yang baik.

\section{Hasil Pengujian Hipotesis}

Setelah diuraikan model pengukuran serta model struktural dari masing-masing variabel, selanjutnya dilakukan pengujian pengaruh masingmasing variabel eksogenus (variabel bebas) terhadap variabel endogenus (variabel terikat) sesuai dengan kerangka pemikiran pada penelitian ini. Pada tahap ini, mengingat model penelitian merupakan model mediasi, maka pengujian dilakukan dengan menggunakan pendekatan step-wise. Pertama menguji pengaruh langsung (direct effect), apakah gaya kepemimpinan initiating structure (IS-L) dan gaya kepemimpinan consideration (C-L) berpengaruh langsung terhadap pemberdayaan psikologis (PP). Kedua menguji pengaruh tidak langsung (indirect effect) dengan memasukkan penggunaan sistem pengukuran kinerja secara diagnostic (SPK-D) dan interactive (SPK-I) sebagai variabel pemediasi.

\section{Pengujian Pengaruh Langsung (Direct Effect)}

Pengujian pengaruh langsung (direct effect) dilakukan tanpa melibatkan variabel pemediasi, yaitu variabel SPK-D dan variabel penggunaan SPK-I. Hasil pengujian pengaruh langsung (direct effect) dengan menggunakan WarpPLS 5.0. Output hasil pengujian direct effect dapat dilihat pada gambar dibawah ini:

Gambar.2 : Hasil Pengujian Direct Effect

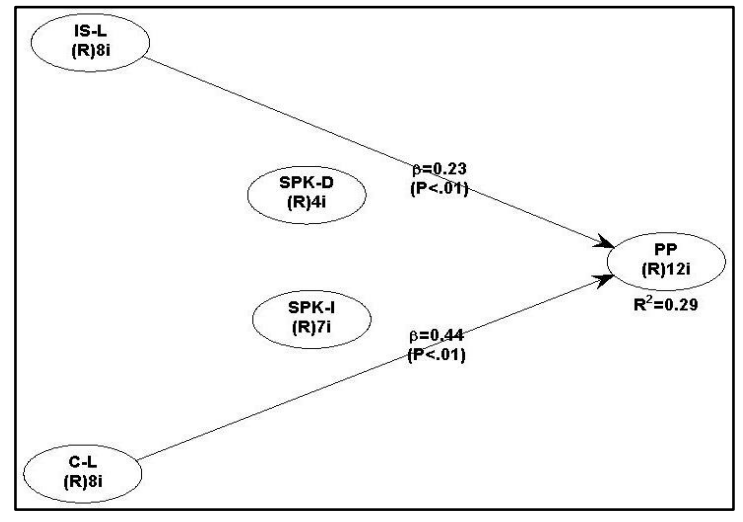

Sumber: Output WarpPLS 5.0 (2018)

Output pada gambar 2 di atas menunjukkan bahwa gaya kepemimpinan initiating strucure (IS-L) berpengaruh positif terhadap Pemberdayaan psikologis (PP) (koefisien: 0,23; $\mathrm{p}<0,01$ ). Oleh karena itu, hipotesis yang menyatakan bahwa IS-L berpengaruh langsung terhadap PP (Hipotesis 1 diterima). Gambar tersebut juga menunjukkan bahwa gaya kepemimpinan cosndieration (C-L) berpengaruh positif terhadap Pemberdayaan psikologis (PP) (koefisien: $0,23 ; \mathrm{p}<0,01)$, yang membuktikan secara 
Jurnal Ilmiah Ekonomi dan Bísnis

Vol. 15. No. 2, September 2018: 186-211

EISSN : $2442-9813$

ISSN : 1829-9822

empiris bahwa C-L berpengaruh langsung terhadap PP (Hipotesis 2 diterima).

\section{Pengujian Pengaruh Tidak Langsung} (Indirect Effect)

Selanjutnya,dilakukan pengujian

pengaruh tidak langsung (indirect effect). Pada tahap ini, pengujian pengaruh tidak langsung (indirect effect) akan melibatkan variabel penggunaan SPK secara diagnostic (SPK-D) dan variabel penggunaan SPK secara interactive (SPK-I).

Hasil pengujian untuk model indirect effect dapat dilihat pada gambar.3.

Gambar.3 : Hasil Pengujian Indirect Effect

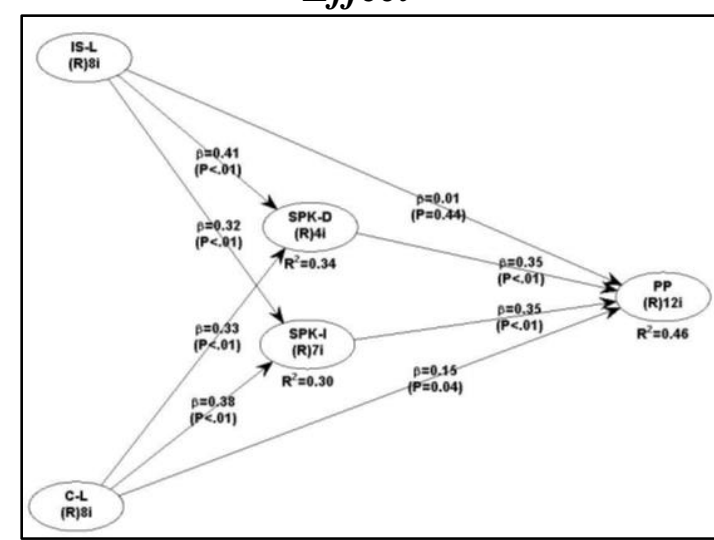

Sumber: Data Primer Diolah, WarpPLS. 5.0 .

Gambar 3 memperlihatkan perolehan nilai $p$-value dan nilai path coefficient $(\beta)$ masing-masing jalur pengujian. Dari output pada gambar yang dirangkum didalam tabel.7 dapat disimpulkan bahwa pada level signifikansi $5 \% \quad(0,05), \quad 6 \quad$ (enam) Hipotesis dari Hipotesis 3 sampai dengan hipotesis 8 diputuskan untuk menerima $\mathrm{H}_{\mathrm{a}}$ dan menolak $\mathrm{H}_{0}$, yang berarti Hipotesis 3 sampai dengan Hipotesis 8 diterima.

Untuk lebih mudahnya dari gambar.3 diatas, peneliti merangkum hasil pengujian tersebut kedalam tabel dibawah ini:

\section{Tabel 2 : Pengujian Pengaruh Tidak Langsung (Indirect effect)}

$\begin{array}{lllll}\begin{array}{l}\text { Hipo } \\ \text { tesis }\end{array} & \text { Path } & \begin{array}{l}\text { P- } \\ \text { Value }\end{array} & \begin{array}{l}\text { Path } \\ \text { Coeffici } \\ \text { ent }\end{array} & \text { Ket } \\ & \text { IS-L } & & & \\ 3 & \rightarrow & <0,001 & 0,413 & \text { Diterima } \\ & \begin{array}{l}\text { SPK-D } \\ \text { IS-L }\end{array} & & & \\ 4 & \rightarrow & <0,001 & 0,320 & \text { Diterima } \\ & \text { SPK-I } & & & \\ 5 & \text { C-L } \rightarrow & & & \\ & \text { SPK-D } & <0,001 & 0,333 & \text { Diterima } \\ 6 & \begin{array}{l}\text { C-L } \rightarrow \\ \text { SPK-I }\end{array} & <0,001 & 0,382 & \text { Diterima } \\ 7 & \begin{array}{l}\text { SPK-D } \\ \text { SP PP }\end{array} & <0,001 & 0,346 & \text { Diterima } \\ 8 & \begin{array}{l}\text { SPK-I } \\ 8\end{array} & <0,001 & 0,355 & \text { Diterima }\end{array}$

Sumber: Data Primer Diolah, WarpPLS. 5.0.

Mengingat model di dalam penelitian ini merupakan model mediasi, maka peneliti akan melakukan analisis tambahan untuk menguji apakah penggunaan SPK secara diagnostic (SPKD) dan interactive (SPK-I) memediasi hubungan antara gaya kepemimpinan (initiating structure dan consideration) dengan pemberdayaan psikologis. Karena itu untuk menjawab pertanyaan tersebut, peneliti merumuskan hipotesis sebagai berikut: Gaya kepemimpinan initiating structure berpengaruh terhadap Pemberdayaan Psikologis di mediasi oleh penggunaan SPK secara interactive (Hipotesis 9). Gaya kepemimpinan initiating structure berpengaruh terhadap pemberdayaan psikologis di mediasi oleh Penggunaan SPK secara diagnostic (Hipotesis 10). Gaya kepemimpinan consideration berpengaruh terhadap pemberdayaan psikologis di mediasi oleh penggunaan SPK secara interactive (Hipotesis 11). Gaya kepemimpinan consideration berpengaruh terhadap pemberdayaan psikologis di mediasi oleh Penggunaan SPK secara diagnostic (Hipotesis 12).

Untuk menguji hipotesis tersebut, ada tiga syarat yang harus dipenuhi (Baron dan Kenny, 1986 dalam Ghozali \& Latan, 
2014:2011). 1) Ada hubungan yang signifikan antara variabel prediktor (eksogen) dan mediator ( $\mathrm{p}$-value $\leq 0,05$ ).

2) Adanya hubungan yang signifikan antara variabel mediator dan criterion (endogen) (p-value $\leq 0,05)$. 3) Hubungan antara variabel prediktor (eksogen) dan criterion (endogen) menjadi tidak signifikan ketika variabel mediator dimasukkan ke dalam model. Selanjutnya untuk mengetahui besarnya variance pengaruh tidak langsung (indirect effect), kita dapat menghitungnya dengan menggunakan metode variance accounted for (VAF) yakni metode yang dikembangkan oleh Preacher (2004) dan Hayes (2008) dari Hair et al., (2013) dalam Sholihin dan Ratmono (2013:81); Ghozali dan Latan (2014:218).

Nilai VAF berkisar antara 0 sampai 1. Semakin tinggi nilai VAF menunjukkan bahwa pengaruh efek mediasi yang sempurna. VAF dapat dihitung dengan cara membagi indirect effect dengan total effect lalu dikali dengan $100 \%$ (Ghozali \& Latan, 2014:218). Dari besaran nilai VAF yang diperoleh maka dapat ditentukan besarnya pengaruh mediasi variabel mediasi tersebut. Nilai VAF $>80 \%$, maka disimpulkan bahwa variabel mediasi merupakan pemediasi penuh (full mediation). Nilai VAF berada antara $20 \%$ dan $80 \%(20 \% \leq \mathrm{VAF} \leq$ $80 \%)$ maka dapat disimpulkan bahwa peran variabel mediasi merupakan mediasi sebagian (partial mediation). Dan jika nilai VAF $<20 \%$, maka dapat disimpulkan bahwa tidak ada efek mediasi.

Terdapat direct effect yang signifikan antara gaya kepemimpinan initiating structure (IS-L) dengan pemberdayaan psikologis (PP), hal ini dibuktikan dengan nilai $p$-value $(0,005)$ yang lebih kecil dari level alpha sebesar $5 \%(0,05)$. Lalu pada tabel.8 juga dapat dilihat pengaruh yang signifikan antara gaya kepemimpinan initiating structure (IS-L) dengan penggunaan SPK secara interactive (SPK-I), hal tersebut dibuktikan dari perolehan nilai p-value $(<0,001)$ yang lebih kecil dari level alpha sebesar 5\% $(0,05)$.

Tabel 3 : Hasil pengujian direct dan indirect effect $\mathrm{H}_{9}$

\begin{tabular}{lcc} 
Path & $\begin{array}{l}\text { Hasil pengujian direct effect } \\
p \text {-value }\end{array}$ & Path coefficient \\
IS-L $\rightarrow$ PP & 0,005 & 0,232 \\
& Hasil pengujian indirect effect \\
& p-value & Path coefficient \\
Path & $<0,001$ & 0,320 \\
IS-L $\rightarrow$ SPK-I & $<0,001$ & 0,355 \\
SPK-I $\rightarrow$ PP & 0,437 & 0,013 \\
IS-L $\rightarrow$ PP & & 0,114 \\
Total Indirect Effect $(0,320 \times 0,355)$ & \\
\multicolumn{2}{c}{ Accounted } & For (VAF) \\
Total Effect $(0,232+0,114)$ & 0,329 \\
Variance &
\end{tabular}

Sumber: Data Primer Diolah, WarpPLS 5.0 (2018)

Pada tabel 3 dapat dilihat bahwa selain itu, juga terdapat pengaruh yang signifikan antara penggunaan SPK secara interactive (SPK-I) dengan pemberdayaan psikologis (PP) yang dibuktikan dari perolehan nilai $p$-value $(<0,001)$ yang lebih kecil dari nilai level alpha sebesar $5 \%$ (0,05). Selain pengaruh direct effect, pada tabel.8 juga dapat dilihat pengaruh tidak langsung (indirect effect) yang tidak signifikan antara gaya kepemimpinan initiating structure (IS-L) dengan pemberdayaan psikologis (PP) ketika penggunaan SPK secara interactive (SPKI) dimasukkan sebagai mediator, hal ini dibuktikan dari perolehan nilai $p$-value $(0,437)$ yang lebih besar dari level alpha $5 \%(0,05)$.

Berdasarkan hal tersebut, maka dapat disimpulkan bahwa penggunaan SPK secara interactive (SPK-I) memediasi hubungan antara variabel gaya kepemimpinan initiating structure (IS-L) dengan variabel pemberdayaan psikologis (PP) (Hipotesis 9 diterima). Selanjutnya pada tabel.8 dapat dilihat perolehan nilai VAF sebesar 0,329, yang menunjukkan peran penggunaan SPK secara interactive 
Jurnal Ilmiah Ekonomi dan Bísnis

Vol. 15. No. 2, September 2018: 186-211

EISSN : $2442-9813$

ISSN : $1829-9822$

(SPK-I) sebagai pemedisasi parsial (partial mediation).

Tabel 4 : Hasil pengujian direct dan indirect effect $\mathrm{H}_{10}$

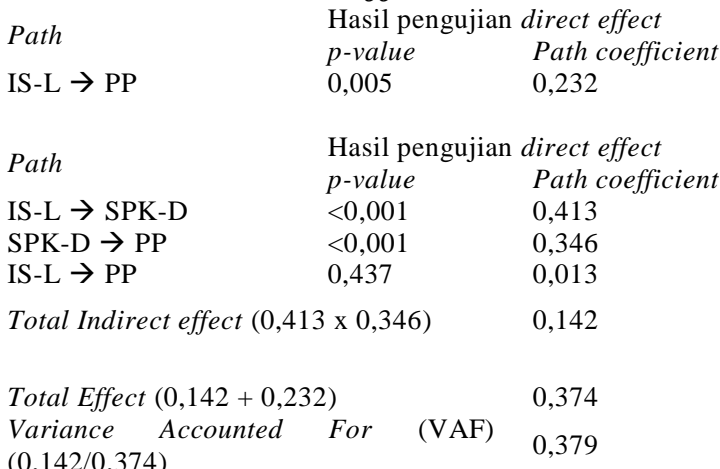

Sumber: Data Primer Diolah, WarpPLS $5.0(2018)$

Dari tabel 4 dapat dilihat direct effect yang signifikan antara gaya kepemimpinan initiating structure (ISL) dengan pemberdayaan psikologis (PP), hal ini dibuktikan dengan perolehan nilai $p$-value $(0,005)$ yang lebih kecil dari level alpha sebesar 5\% $(0,05)$. Dari tabel.9 juga dapat disimpulkan bahwa terdapat pengaruh yang signifikan antara gaya kepemimpinan initiating structure (ISL) dengan penggunaan SPK secara diagnostic (SPK-D), yang dapat dilihat dari perolehan nilai $p$-value $(<0,001)$ yang lebih kecil dari level alpha sebesar $5 \%$ (0,05). Pada tabel tersebut juga memperlihatkan pengaruh signifikan antara penggunaan SPK secara diagnostic (SPK-D) dengan pemberdayaan psikologis (PP) yang dibuktikan dari perolehan nilai $p$-value $(<0,001)$ yang lebih kecil dari nilai level alpha sebesar 5\% (0,05). Selain itu, pada tabel tersebut juga memperlihatkan bahwa terdapat pengaruh tidak langsung (indirect effect) yang tidak signifikan antara gaya kepemimpinan initiating structure (IS-L) dengan pemberdayaan psikologis (PP) ketika penggunaan SPK secara diagnostic (SPK-D) dimasukkan sebagai mediator, hal ini dibuktikan dari perolehan nilai $p$-value $(0,437)$ yang lebih besar dari level alpha 5\% (0,05).
Berdasarkan hal tersebut, maka dapat disimpulkan bahwa penggunaan SPK secara diagnostic (SPK-D) memediasi hubungan antara variabel gaya kepemimpinan initiating structure (IS-L) dengan variabel pemberdayaan psikologis (PP) (Hipotesis10 diterima). Nilai VAF sebesar 0,379 yang terdapat pada tabel.9 menunjukkan bahwa peran penggunaan SPK secara diagnostic (SPK-D) sebagai pemedisasi parsial (partial mediation).

Pada tabel 5 dapat dilihat bahwa terdapat direct effect yang signifikan antara gaya kepemimpinan consideration (C-L) dengan pemberdayaan psikologis (PP), hal ini tersebut dibuktikan dengan perolehan nilai $p$-value $(0,005)$ lebih kecil dari alpha sebesar 5\% $(0,05)$, dan dari tabel tersebut juga dapat dilihat bahwa terdapat pengaruh yang signifikan antara gaya kepemimpinan consideration (C-L) dengan penggunaan SPK secara interactive (SPK-I), yang dibuktikan dari perolehan nilai $p$-value $(<0,001)$ yang lebih kecil dari alpha sebesar 5\% $(0,05)$. Tabel.10 juga memperlihatkan bahwa terdapat pengaruh signifikan antara penggunaan SPK secara interactive (SPKI) dengan pemberdayaan psikologis (PP) yang dibuktikan dari perolehan nilai $p$ value $(<0,001)$ yang lebih kecil dari nilai alpha sebesar $5 \%(0,05)$ dan terdapat pengaruh indirect effect yang tidak signifikan antara gaya kepemimpinan consideration (C-L) dengan pemberdayaan psikologis (PP) ketika penggunaan SPK secara interactive (SPKI) dimasukkan sebagai mediator, hal ini dibuktikan dari perolehan nilai $p$-value $(0,044)$ yang lebih kecil dari nilai alpha $5 \%(0,05)$.

\footnotetext{
Tabel 5 : Hasil pengujian direct dan indirect effect $\mathrm{H}_{11}$

Path Hasil pengujian direct effect
} 


\begin{tabular}{|c|c|c|}
\hline $\mathrm{C}-\mathrm{L} \rightarrow \mathrm{PP}$ & $\begin{array}{l}p \text {-value } \\
<0,001\end{array}$ & $\begin{array}{l}\text { Path coefficient } \\
0,439\end{array}$ \\
\hline Path & \multicolumn{2}{|c|}{ Hasil pengujian direct effect } \\
\hline$C_{T}$ & $p$-value & Path coefficient \\
\hline $\mathrm{C}-\mathrm{L} \rightarrow \mathrm{SPK}-\mathrm{I}$ & $<0,001$ & 0,382 \\
\hline SPK-I $\rightarrow$ PP & $<0,001$ & 0,355 \\
\hline $\mathrm{C}-\mathrm{L} \rightarrow \mathrm{PP}$ & 0,044 & 0,154 \\
\hline Total Indirect Effect $(0,382$ & $0,355)$ & 0,136 \\
\hline Total Effect $(0,439+0,136$ & & 0,575 \\
\hline $\begin{array}{l}\text { Variance Accounted } \\
(0,136 / 0,575)\end{array}$ & (VAF) & 0,237 \\
\hline
\end{tabular}

Sumber: Data Primer Diolah, WarpPLS 5.0 (2018)

Berdasarkan informasi yang terdapat pada tabel 5 yang telah dipaparkan sebelumnya maka dapat disimpulkan bahwa penggunaan SPK secara interactive (SPK-I) memediasi hubungan antara variabel gaya kepemimpinan consideration (C-L) dengan variabel pemberdayaan psikologis (PP) (Hipotesis 11 diterima). Selanjutnya nilai VAF sebesar 0,237 menunjukkan bahwa peran penggunaan SPK secara interactive (SPK-I) sebagai pemedisasi parsial (partial mediation).

Tabel.11 memperlihatkan bahwa terdapat direct effect yang signifikan antara gaya kepemimpinan consideration (C-L) dengan pemberdayaan psikologis (PP), hal ini dibuktikan dengan nilai $p$-value $(0,005)$ yang lebih kecil dari level alpha sebesar $5 \%(0,05)$. Selain itu terdapat pengaruh yang signifikan antara gaya kepemimpinan consideration (C-L) dengan penggunaan SPK secara diagnostic (SPK-D), hal tersebut dibuktikan dari perolehan nilai $p$-value $(<0,001)$ yang lebih kecil dari level alpha sebesar $5 \% \quad(0,05)$. Terdapat pengaruh yang signifikan antara penggunaan SPK secara diagnostic (SPK-D) dengan pemberdayaan psikologis (PP) yang dibuktikan dari perolehan nilai $p$-value $(<0,001)$ yang lebih kecil dari nilai level alpha sebesar $5 \%$ (0,05); Terdapat pengaruh tidak langsung (indirect effect) yang tidak signifikan antara gaya kepemimpinan consideration (C-L) dengan pemberdayaan psikologis (PP) ketika penggunaan SPK secara diagnostic (SPKD) dimasukkan sebagai mediator, hal ini dibuktikan dari perolehan nilai $p$-value $(0,044)$ yang lebih kecil dari level alpha $5 \%(0,05)$. Berdasarkan informasi pada tabel.11 yang telah dipaparkan, maka dapat disimpulkan bahwa penggunaan SPK secara diagnostic (SPK-D) memediasi hubungan antara variabel gaya kepemimpinan consideration (C-L) dengan variabel pemberdayaan psikologis (PP) (Hipotesis 12). Selanjutnya pada tabel.11 dapat dilihat perolehan nilai VAF sebesar 0,208, yang menunjukkan peran penggunaan SPK secara diagnostic (SPKD) sebagai pemedisasi parsial (partial mediation).

\section{Tabel 6 : Hasil pengujian direct dan} indirect effect $\mathrm{H}_{12}$

\begin{tabular}{|c|c|c|}
\hline & Hasil penguji & $\mathrm{n}$ direct effect \\
\hline Path & $p$-value & Path coefficient \\
\hline $\mathrm{C}-\mathrm{L} \rightarrow \mathrm{PP}$ & $<0,001$ & 0,439 \\
\hline Path & Hasil penguji & $\mathrm{n}$ direct effect \\
\hline Pain & $p$-value & Path coefficient \\
\hline $\mathrm{C}-\mathrm{L} \rightarrow \mathrm{SPK}-\mathrm{D}$ & $<0,001$ & 0,333 \\
\hline SPK-D $\rightarrow$ PP & $<0,001$ & 0,346 \\
\hline $\mathrm{C}-\mathrm{L} \rightarrow \mathrm{PP}$ & 0,044 & 0,154 \\
\hline Total Indirect Effect $(0,333$ & $0,346)$ & 0,115 \\
\hline Total Effect $(0,439+0,115)$ & & 0,554 \\
\hline $\begin{array}{l}\text { Variance Accounted } \\
(0,115 / 0,554)\end{array}$ & (VAF) & 0,208 \\
\hline
\end{tabular}

Sumber: Data Primer Diolah, WarpPLS 5.0 (2018)

Berdasarkan hasil pengujian hipotesis analisis tambahan maka dapat disimpulkan bahwa secara umum penggunaan SPK secara diagnostic (SPKD) dan penggunaan SPK secara interactive (SPK-I) memediasi hubungan antara gaya kepemimpinan initiating structure (IS-L) dan gaya kepemimpinan consideration (C-L) dengan pemberdayaan psikologis. Hal serupa juga disampaikan oleh Putri, G. E., \& Kamilah, F. (2018). 
Jurnal Ilmiah Ekonomi dan Bísnis

Vol. 15. No. 2, September 2018: 186-211

EISSN : $2442-9813$

ISSN : : 1829-9822

\section{KESIMPULAN DAN SARAN}

Secara umum hasil penelitian ini mendukung seluruh dugaan-dugaan pada hipotesis yang telah dirumuskan sebelumnya, diantaranya adalah hipotesis yang menyatakan bahwa gaya kepemimpinan initiating structure dan gaya kepemimpinan consideration berpengaruh terhadap pemberdayaan psikologis, dan hipotesis mediasi yang menyebutkan bahwa penggunaan SPK secara diagnostic dan interactive memediasi hubungan gaya kepemimpinan initiating structure dan consideration dengan pemberdayaan psikologis. Namun, penelitian ini tidak terlepas dari beberapa keterbatasan, yaitu:Peneliti ini hanya dilakukan pada karyawan yang bekerja di bagian keuangan pada Universitas di teritorial kota Pekanbaru saja, yang belum mewakili populasi karyawan yang bekerja di bagian keuangan pada Universitas di seluruh Indonesia; Peneliti tidak melakukan komparasi pengaruh antara gaya kepemimpinan initiating structure dengan gaya kepemimpinan consideration dalam mempengaruhi pemberdayaan psikologis; Penelitia ini juga tidak mengkomparasi pengaruh antara penggunaan SPK secara diagnostic dan penggunaan SPK secara interactive dalam mempengaruhi pemberdayaan psikologis. Pada model penelitian yang dikemukakan, peneliti tidak menguji pengaruh dari pemberdayaan psikologis terhadap kinerja manajerial;

Memperhatikan keterbatasanketerbatasan didalam penelitian ini, maka ada beberapa saran yang diberikan untuk penelitian selanjutnyanya. Saran-saran tersebut adalah sebagai berikut: Memperluas sampel, agar sampel dapat mewakili populasi karyawan yang bekerja dibagian keuangan di seluruh Indonesia sehingga hasil dari penelitian dapat digeneralisasi; Penelitian selanjutnya sebaiknya meneliti dengan membandingkan antara gaya kepemimpinan initiating structure dengan gaya kepemimpinan consideration dalam mempengaruhi pemberdayaan psikologis. Peneliti selanjutnya sebaiknya meneliti dengan membandingkan antara penggunaan SPK secara diagnostic dengan penggunaan SPK secara interactive dalam mempengaruhi pemberdayaan psikologis. Peneliti selanjutnya harus mampu mengembangkan model penelitian dengan menambahkan variabel kinerja manajemen sebagai variabel endogenous terhadap pemberdayaan psikologis karyawan.

\section{DAFTAR PUSTAKA}

Abbas, Yusra., 2013, Motivasi Intrinsik, Motivasi Ekstrinsik, Kompetensi dan Kinerja Guru dalam Jurnal Humanitas, Vol.X No.1 Januari 2013.

Abernethy, Margaret A. Jan Bouwens, dan Laurence van Lent., 2010, Leadership ans control system design, dalam Management Accounting Reasearch 21 (2010) 2-16, ScienceDirect-Elsevier.

Amir Khani, Amir Hossein, and Mansoreh Derakhshan., 2016, Studying the Effect of Leadership Styles on Psychological Empowerment of Mihan Carton Employees dalam International Research Journal of Management Sciences. Vol., 4(1),23-30, ISSN 2147-964X

Anthony, R.N. and V. Govindarajan. 2007. Management Control System 12th, Mc-Graw-Hill. New York.

Al-Tarawneh, H.A. dan M.M., Mubaslat., 2011, Design and Use of Management and Control System in The Jordanian University, dalam International Journal of Accounting and Finance Reporting, Vol.1., No.1, hlm 242254. 
Astutik, Septiyani Putri., 2017, Pengaruh Motivasi Intrinsik terhadap Hubungan Antara Gaya Kepemimpinan Konsiderasi dengan Kinerja Karyawan (Studi Kasus di PT. Wijaya Tour \& Travel) dalam Jurnal Manajemen Dirgantara Vol. 10; Juli 2017.

Aura Pratadina, Ria Nelly Sari, dan Al Azhar L., 2015, Pengaruh Sistem Pengendalian Manajemen terhadap Kreatifitas Manajer dengan Motivasi sebagai Variabel Intervening, dalam Jurnal Ekonomi, Manajemen dan Akuntansi I Vol. 25 No.2 Desember 2015, Fakultas Ekonomi Universitas Riau, Pekanbaru.

Ayu Purnama., 2013, Peranan Gaya Kepemimpinan Dan Sistem Pengendalian Manajemen Terhadap Loyalitas Karyawan Di Perusahaan Keluarga PT. Sus Surabaya, dalam Jurnal Ilmiah Mahasiswa Universitas Surabaya, Vol.2, No.2. Universitas Surabaya.

Bastian, Indra, 2014. Sistem Pengendalian Manajemen Sektor Publik Mempertahankan Kepentingan Masyarakat. Salemba Empat: Jakarta.

Bisbe, J., dan Otley, D., 2004. The Effects of Interactive Use of Management Control Systems On Product Innovation, dalam Accounting, Organizations and Society 29 (8), 709-737.

Bonner, S.E. dan Sprinkle G.B., 2002, The effects of monetary incentives on effort and task performance: theories, evidence, and a framework for research, dalam Accounting, Organizations and Society 27: pp. 303-345.
Bobe, B.J., dan D.W. Taylor., 2010, Use of Management Control System in University Faculties: Evidence of Diagnostic versus Interactive Approaches by The Upper Echelons, dalam The Sixth Asia Pacific Interdisciplinary Research in Accounting Conference, Sydney, July 2010.

Castro, C.B., Perinan, M.M., dan Bueno, J.C.C., 2008, Transformasional Leadership and Followers Attitude: The Mediating Role of Psychologycal Empowerment, dalam The International Journal of Human Resource Management. 19(10), 1842-1863.

Cowley, E., \& Smith, S. (2013). Motivation and mission in the public sector: Evidence from the world values survey. Theory and Decision, 76(2), 241-263. doi:http://dx.doi.org/10.1007/s112 38-013-9371-6.

Dastes, N., Natajaya, I.N., Yudana, I.M., Sunu, I.G.K.A., dan Dantes, K.R., 2013, Analisis Eksploratoris Kebijakan Pengembangan dan Pembinaan Kepegawaian Universitas Pendidikan Ganesha, dalam Laporan Penelitian Institusional Kebijakan Institusi, Universitas Pendidikan Ganesha.

Dossi, A dan Patelli, L., 2010, You Learn From What You Measure: Financial And Non-Financial Performance Measures In Multinational Companies, dalam Long Range Planning 43 (4), 498526.

Djuwita, T.M., 2011. Pengembangan Sumber Daya Manusia dan Produktivitas Kerja Pegawai., dalam Manajerial, 10(19), pp.1521. 
Jurnal Ilmiah Ekonomi dan Bísnis

Vol. 15. No. 2, September 2018: 186-211

EISSN : $2442-9813$

Edi Suharto., 2009, Membangun Masyarakat Memberdayakan Rakyat Kajian. Kajian Strategis Pembangunan Kesejahteraan Sosial. Bandung: Rafika Aditama.

Ester Manik., 2010, Pengaruh Struktur Kepemilikan, Budaya Organisasi Dan Kepemimpinan Transformasional Terhadap Tata Kelola Perusahaan Yang Baik Serta Implikasinya Pada Kinerja Keuangan Perusahaan (Studi Pada BUMN di Indonesia, Disertasi Program Doktor Ilmu Manajemen Pascasarjana Universitas Pasundan, Bandung.

Efferin, S, and T. Hopper., 2007, Management control, culture and ethnicity in a Chinese Indonesian company, dalam Accounting, Organizations, and Society, Vol. 32, hlm 223-262.

Ferreira, A dan Otley, D., 2009, The Design and Use of Performance Management Systems: An Extended Framework For Analysis, dalam Management Accounting Research 20 (4), 263-282.

George dan Jones., 2005, Understanding and managing Organizational Behavior 4th Edition, Pearson Prentice Hall.

Putri, G. E., \& Kamilah, F. (2018). Pengaruh Komitmen Manajemen dan Otoritas Pengambilan Keputusan Terhadap Pengembangan Sistem Pengukuran Kinerja Instansi Pemerintah. Jurnal Daya Saing, 4(2), 227-233.

Hall, Matthew., 2008, The Effect of Comprehensive Performance
Measurement System on Role Clarity, Psychological Empowerment and Managerial Performance, dalam Accounting, Organization and Society 33, 141163, ScienceDirect-Elsevier.

Hartmann, F.G.H.; Naranjo-Gil, D. \& Perego, P., 2010. The Effects of Leadership Styles and Use of Performance Measures on Managerial Work-Related Attitudes, dalam European Accounting Review 19, 275-310.

Hasibuan, Malayu S.P, 2007, Organisasi dan Motivasi: Dasar Peningkatan Produktifitas, Bumi Aksara: Jakarta.

Henri, Jean-Francois., 2006, Management control systems and strategy: A resource-based perspective, dalam Accounting, Organizations and Society 31, 529-558, ScienceDirect-Elsevier.

Herb Schoch, Shopia Su Kevin Baird., (2017), Management control systems: the role of interactive and diagnostic approaches to using controls from an organizational life cycle perspective, dalam Journal of Accounting \& Organizatiional Change Vol. 13 Iss 1 pp, EmeraldInsight.

Heru, B Kesatria Septian. 2013. Analisis Pengaruh Gaya Kepemimpinan Transformasional Dan Pemberdayaan Psikologis Terhadap Komitmen Organisasional Dalam Meningkatkan Kinerja Karyawan (Studi Pada PT. Bank Jawa Tengah Semarang). Tesis Program Studi Magister Manajemen Universitas Diponegoro. Semarang. 
Hernando, Rizki., 2016, Pengaruh Gaya Kepemimpinan Manajer Dan Penggunaan Pengukuran Kinerja Terhadap Sikap Dan Perilaku Bawahan. Tesis Program Magister Sains Akuntansi Universitas Gadjah Mada. Yogyakarta.

Hinkin, T.T., dan Schriesheim, C.A., 2015, Leader reinforcement, behavioral integrity, and subordinate outcomes: A social exchange approach, dalam The Leadership Quarterly 26 (2015) 991-1004. Elsevier.

Hossein, Amir., Amir Khani., and Mansoreh Derakhshan., 2016, Studying the Effect of Leadership Styles on Psychological Empowerment of Mihan Carton Employees dalam International Research Journal of Management Sciences, Vol.,4 (1), 23-30. 2016 ISSN 2147-964X.

Hoque, Z., dan M. Chia., 2012, Competitive Forces and The Levers of Control Framework in a Manufacturing Setting A Tale of a Multinational Subsidiary, dalam Qualitative Research Accounting \& Management, Vol.9, No.2, hlm 123-145

Huang, Yin-Tsuo., 2015, A Discussion of Leadership Styles and Performance Management in MNEs, dalam Journal of Accounting Finance \& Management Strategy, Vol. 10, No.1, Jun 2015, pp51-82.

International Labour Organization, 2013, Manajemen Sumber Daya Manusia untuk Kerjasama dan Usaha yang Sukses, Jakarta: ILO, 2013.

Ittner, C.D., Larcker, D.F., dan Meyer, M.W., 2003, Subjectivity And
The Weighting of Performance Measures: Evidence From a Balanced Scorecard, dalam The Accounting Review 78 (3), 725758.

Jantje Eduard Lekatompessy., 2012, Peran Sistem Pengendalian Manajemen Dalam Meningkatkan Kinerja Perusahaan: Analisis Kontijensi dan Resource-Based View, Disertasi Program Studi Doktor Ilmu Manajemen Universitas Diponegoro, Semarang.

Jarvenpaa, M., dan A. Lansiluoto., 2011, Link ages Between the Elements of Management Control System in A Non-Profit Organization, paper from SSRN.

George dan Jones., 2005, Understanding and managing Organizational Behavior 4th Edition, Pearson Prentice Hall.

Kadarisman., 2012, Manajemen Pengambangan Sumber Daya Manusia, Rajagrafindo Persada, Jakarta.

Khairiyah, Diah., 2015, Pengaruh Penggunaan Sistem Pengukuran Kinerja secara Diagnostik dan Interaktif terhadap Kinerja Manajerial dengan Variabel Mediasi Ambituitas Peran Dan Pemberdayaan Psikologis. Tesis Program Magister Akuntansi Universitas Gadjah Mada. Yogyakarta.

Koesindratmono., Ferry dan Berlian Gressy Septarini., 2011, Hubungan antara Masa Kerja dengan Pemberdayaan Psikologis pada Karyawan PT. Perkebunan Nusantara X (Perseora), dalam Jurnal INSAN Vol,13 No. 01, Departemen Psikologi Industri dan Organisasi 
Jurnal Ilmiah Ekonomi dan Bísnis

Vol. 15. No. 2, September 2018: 186-211

EISSN : $2442-9813$

ISSN : 1829-9822

Fakultas Psikologi Universitas Airlangga, Surabaya.

Kreitner, R., \& Kinicki, A., 2008, Organizational behavior. $8^{\text {th }}$ ED.

McGraw-Hill Inc, International Edition, New York.

Locke, E. A., dan Latham, G.P., 1990, A

Theory of Goal Setting and Task Performance, Prentice Hall, Englewood Cliffs, NJ.

Locke, E. A., dan Latham, G.P., 2002, Building a practically useful thepry of Goal Setting and Task Motivation: a 35-year odyssey, dalam American Psychologist 57 (9), 705-717.

Lora., 2016, Pengaruh Levers Of Control Terhadap Pemberdayaan Psikologis Dan Kinerja Di Perusahaan Farmasi PT RAM. Tesis Program Studi Magister Manajemen Fakultas Ekonomi Dan Bisnis Universitas Gadjah Mada, Yogyakarta.

Luthans, F., 2006. Perilaku Organisasi, Edisi Sepuluh, Andi, Yogyakarta.

Mahfud Sholihin dan Dwi Ratmono., 2013, Analisis SEM-PLS dengn WarpPLS 3.0 untuk Hubungan Nonlinear dalam Penelitian Sosial dan Bisnis, Andi, Yogyakarta.

Mahama, H. 2006. Management Control Systems, Cooperation and Performance in Strategic Supply Relationships: A Survey in the Mines, dalam Management Accounting Research 17 (2): 315-339.

Marginson, D. \& Ogden, S., 2005a. Coping with ambiguity through the budget: the positive effects of budgetary targets on managers' budgeting behaviours, dalam
Accounting, Organizations and Society 30, 435-456

2005b. Managers, budgets and organizational change: unbundling some of the paradoxes, dalam Journal of Accounting and Organizational Change 1, 45-62, Emerald Insight.

Marginson, D., 2006, Information processing and management control: a note exploring the role played by information media in reducing role ambiguity, dalam Management Accounting Research 17 (2), 187-197, ScienceDirectElsevier.

Marginson, D; McAulay, L.; Roush, M. \& Zijl T., 2014. Examining a positive psychological role for performance measures, dalam Management Accounting Research 25, 63-75, ScienceDirect-Elsevier.

M, Sholihin dan Pike, R., 2009, Fairness in performance evaluation and its behavioural consequences, dalam Accounting and Business Research 39 (4), 397-413

Muftah, M., \& Galea, S. R. (2013). Language learning motivation among Malaysian pre-university students. English Language Teaching, 6(3), 92-103.

Muhammad Ali Sukrajap., 2016, Pengaruh Kepemimpinan Transformasional Terhadap Kepuasan Kerja Dan Komitmen Organisasional Dengan Dimediasi oleh Pemberdayaan Psikologis, dalam Jurnal Psikologi, Vol.12, September 2016, 22-45, Pusat Data Psikologi Universitas Proklamasi 45, Yogyakarta. 
Mundy, J., 2010, Creating Dynamic Tensions Through a Balanced Use of Management Control Systems, dalam Accounting, Organizations and Society 35 (5), 499-523.

Nguyen, Thi Thu, et al., 2017, Effect of transformational-leadership style and management control system on managerial performance, dalam Journal of Business Research 70 (2017): 202-213. https://doi.org/10.1016/j.jbusres. 2016.08.018.

Nur Ida Iriani., 2010, Motivasi Intrinsik, Motivasi Ekstrinsik dan Disiplin Kerja Pengaruhnya terhadap Kinerja Pegawai pada Kantor Dinas Pendidikan Kabupaten Sambas, dalam Jurnal Aplikasi Manajemen Vol.8, No.2, Mei 2010.

Otley, D. 1980, The Contingency Theory of Management Accounting: Achievements and Prognosis, dalam Accounting, Organizations and Society, 5 (3): 413-428.

Pramesti, Wulan., 2009, Motivasi: Pengertian, Proses dan Arti Penting Dalam Organisasi dalam Jurnal Ekonomi dan Ilmu Sosial, Vol 5., No. 1., ISBN: 1858-4071.

Radianto, Wirawan Endro, 2015, Sistem Pengendalian Manajemen Di Enterpreneurial University, dalam Jurnal Akuntansi Multiparadigma (JAMAL) Volume 6, Nomor 2, Halaman 175-340.

Ramdhan, Deden., 2015, Kepemimpinan Transformasional dan Pemberdayaan Psikologis terhadap Komitmen Organisasi dan Implikasinya Kinerja Pegawai, dalam Jurnal Kontigensi Volume 3, No.2, November 2015, Hal. 117 128. ISSN 2088-4877.

Ristauli Debora Sianipar, 2013, Pengaruh Sistem Pengukuran Kinerja Dan Sistem Reward Terhadap Kinerja Manajerial, dalam Artikel yang disusun berdasarkan skripsi, Program Studi Akuntansi Fakultas Ekonomi Universitas Negeri Padang.

Robbins, S. P., 2003, Organizational behavior. $10^{\text {th }}$ ED. Prentice Hall International, New Jersey.

Samsuni, S. (2017). Manajemen sumber daya manusia. Al-Falah: Jurnal Ilmiah Keislaman dan Kemasyarakatan, 17(1), 113-124.

Siagian, Sondang., 2002, Manajemen Sumber Daya Manusia. Jakarta: PT. Bumi Aksara.

Simons, R., 2000, Performance Measurement and Control Systems for Implementing Strategy. Prentice-Hall, Englewood Cliffs, NJ.

Simons, R., 2005, Levers of Organizational Design: How Managers Use Accountability Systems for Greater Performance and Commitment, Harvard Business School Press, Boston, MA.

Soekarso, \& Iskandar Putong., 2015, Kepemimpinan: Kajian Teoritis dan Praktis. Retrieved from: https://books.google.co.id/books?i d, diakses 28 Maret 2017.

Stephen P. Robbins and Timothy A. Judge., 2008, Perilaku Organisasi Edisi 12 Buku 1. Terjemahan: Diana 
Jurnal Ilmiah Ekonomi dan Bisnis

Vol. 15. No. 2, September 2018: 186-211

EISSN : $2442-9813$

ISSN : 1829-9822

Angelica, Ria Cahyani dan Abdul Rosyid, Jakarta: Salemba Empat.

Surifah, S., Mustiati, E., Syaifullah, M. Z., \& Bowo, A. N. A. (2016). Pengaruh motivasi terhadap minat mahasiswa mengikuti pendidikan profesi akuntans dalam Jurnal Kependidikan, 46(2), 246-258

Syaiful Rahman, Muhammad Nasir dan Sri Handayani., 2007, Pengaruh Sistem Pengukuran Kinerja Terhadap Kejelasan Peran, Pemberdayaan Psikologis dan Kinerja Manajerial, dalam Simposium Nasional Akuntansi X, Makassar 26-28 Juli 2007.

Spekle, Roland F dan Verbeteen, Frank H.M., 2013, The Use of Performance Measurement System in The Public Sector: Effects on Performance, dalam Management Accounting Research $x x x$ (2013) $x x x-x x x$, ScinceDirect-Elsevier.

Spkle, Roland F., 2014, Creativity and Control: A Paradox. Evidence from the Leves of Control Framework, GMARS in Sydney Australia.

Spreitzer, Gretchen M., 1995, Psychological empowerment in the workplace: Dimensions, measurement and validation, dalam Academic of Management Journal, 38 (5), 1442-1465.

,1996, Social Structural Characteristics Of Psychological Empowerment, dalam Academy of Management Journal, Vol.39. No.2., 483-504.
Spreitzer, G.M., Kizilios, M.A., \& Nason, S.W., 1997, A Dimension Analysis Of The Relationship Beetwen Psychological Empowerment And Effectiveness, Satisfaction, And Strain, dalam Journal of Management 23, 5, 670-704.

Simons, R., 2000, Performance Measurement and Control Systems for Implementing Strategy. Prentice Hall, Upper Saddle River, New Jersey

Sugiyono., 2011, Statistika Untuk Penelitian, Alfabeta, Bandung.

Sutoyo \& Mahardhika, Desta., 2015, Pengaruh Sistem Pengendalian Manajemen Dan Budaya Organisasi Terhadap Kinerja Organisasi (Studi Kasus Pada Pemerintah Daerah Provinsi Daerah Istimewa Yogyakarta), dalam Buletin Ekonomi Vol.13, No.2, Desember 2015, hal 139270.

Syaiyid, Elzi., Hamidah Nayati Utami dan Muhammad Faisal Riza., 2013., Pengaruh Gaya Kepemimpinan terhadap Motivasi Kerja dalam Jurnal Administrasi Bisnis (JAB)., Vol. 1 No.1 April 2013.

Tanjung, Amris Rusli dan Yesi Mutia Basri., 2017, The Effect Of Leadership Styles On Goal Clarity And Fairness: Mediated Used Performance Measure dalam International Journal of Scientific \& Technology Research Volume 6, ISSUE 04, ISSN 2277-8616.

Tanjung, Amris Rusli., dan Yesi Mutia Basri, dan Tuti Dasrita., 2015, Hubungan Sistem Pengukuran Kinerja dengan Kinerja Manajerial: Peran Keadilan 
Prosedural, Kejelasan Peran, dan Komitmen Organisasi sebagai Variabel Pemediasi, dalam Jurnal Sorot, Volume 10, Nomor 2, Oktober 2015 halaman 195210, Lembaga Penelitian dan Pengabdian Kepada Masyarakat Univesitas Riau.

Tessier, Sophie dan Otley, David., 2012, A conceptual Development of Simons' Levers of Control Framework, dalam Management Accounting Research, 23, 171185, ScienceDirect-Elsevier.

Thomas, K. W., \& Velthouse, B. A., 1990, Cognitive Elements of Empowerment: An "Interpretive" Model Intrinsic Task Motivation, dalam Academic of Management Review. 15 (4), 666-681.

Undang-undang Nomor 20 Tahun 2003 tentang Sistem Pendidikan Nasional. Lembaran Negara RI Tahun 2003, Sekretaris Negara Republik Indonesia.

Undang-undang Nomor 12 Tahun 2012 tentang Pendidikan Tinggi. Lembaran Negara Nomor 158, Sekretariat Negara Republik Indonesia. Tambahan Lembaran Negara Nomor 5336.

Penjelasan atas Undang-undang Nomor 12 Tahun 2012 tentang Pendidikan Tinggi. Lembaran Negara Nomor 5336, Sekretariat Negara Republik Indonesia

Usman Dachlan., 2014, Panduan lengkap structural equation modeling Tingkat Dasar; Metodologi, Konsepsi, Aplikasi (Dengan $A M O S)$, Lentera Ilmu, Semarang.
United Nations Development Programme (UNDP), 2016, Human Development Report 2016, New York 10017 USA. ISBN: 978-921-126413-5.

Vandenbosch, Betty., 1999, An Empirical Analysis of The Association Between The Use of Executive Support Systems and Perceived Organizational Competitiveness, dalam Accounting, Organizations and Society 24 (1), 77-92, ScienceDirect-Elsevier.

Webb, R.A., 2004. Managers' Commitment To The Goals Contained In A Strategic Performance Measurement System, dalam Contemporary Accounting Research 21 (4), 925-958.

Widener, S.K., 2007, An Empirical Analysis of The Levers of Control Framework, dalam Accounting, Organizations and Society 32, 757-788, ScienceDirect-Elsevier.

Wongkaew, W., 2013, Management Accounting and Control SystemUnnecessary Evils to Innovation, dalam Chulalongkorn Business Review, Vol.34 No.3., 1-21.

Yukl, G., 2010, Leadership in Organizations, Edisi 7th. Pearson, Upper Saddle River, NJ.

Zaini, Arifin., 2016, Analisa Pengaruh Motivasi, Kemampuan Kerja, Dan Kepuasan Kerja Terhadap Kinerja Pegawai Universitas Tridinanti Palembang dalam Jurnal Desiminasi Teknologi, Vol.4., Nomor 1., Januari, 2016. ISSN 2303-212X. Universitas Tridinanti Palembang. 